\title{
PEKERJA ANAK DALAM KAJIAN ETIS DEONTOLOGIS
}

\section{Gerald Latuserimala}

\begin{abstract}
Not something wrong if we say that the problem of child labor is an issue that is closely related to Human Rights (HAM). This is a serious problem and a threat to the future life of the nation in the future if the government, churches, parents and all the relevant elements do not put anxiety by delivery solutional steps in resolving this issue. Posts in this article is part of the anxiety itself. Although the study of thought ethical deontological mapped still far from expected, but at least this article can serve as an invitation for us to be more sensitive again to turn the face of the children as a result of the role of child labor that has robbed the basic rights of their humanity. The beginning of this article, the author explains the facts of child labor in Indonesia. Further theoretical studies of children from the perspective of developmental psychology, work and child protection (law) and ends with a deontological ethical studies.
\end{abstract}

Keywords: Child labor and deontological ethical

\begin{abstract}
Abstrak
Bukan sesuatu yang keliru jika kita katakan bahwa masalah pekerja anak adalah masalah yang berhubungan erat dengan apa itu Hak Asasi Manusia (HAM). Hal ini adalah Masalah yang serius dan akan menjadi ancaman bagi masa depan kehidupan bangsa di masa yang akan datang jika pemerintah, gereja, orang tua serta semua elemen yang terkait tidak menaruh kegelisahan demi melahirkan langkah-langkah yang solutif dalam penyelesaian masalah ini. Tulisan dalam artikel ini adalah bagian dari kegelisahan itu sendiri.Walaupun kajian pikir etis deontologis yang dipetakan masih jauh dari yang diharapkan, namun setidaknya tulisan ini bisa dijadikan sebagai ajakan untuk kita agar lebih peka lagi dalam memalingkan wajah terhadap anak-anak akibat dari peran sebagai pekerja anak yang telah merenggut hak-hak dasar kemanusiaan mereka. Awal dari tulisan ini penulis memaparkan fakta pekerja anak yang ada di indonesia. Selanjutnya kajian teoritik tentang anak dari sudut pandang psikologi perkembangan, kerja dan perlindungan anak (hukum) dan diakhiri dengan kajian etis deontologis.
\end{abstract}

Kata Kunci:Pekerja anak dan etis deontologis

\section{A. Pendahuluan}

\section{A.1. Fakta Pekerja Anak}

Pekerja anak merupakan subjektifitas sosial yang menarik untuk terus diperbincangkan, Eksistensinya pun menjadi sorotan dalam mewarnai wacana yang 
turut menghadirkan perhatian serius dari berbagai kalangan baik pemerintah (pusatdaerah) maupun lembaga-lembaga sosial masyarakat yang bergerak untuk menegaskan dan memenangkan hak-hak anak yang sengaja direnggut oleh oknumoknum tertentu.Mereka dipakai sebagai pekerja-pekerja muda (6-15 tahun), entah itu di jermal-jermal industri maupun pada kelompok-kelompok kecil masyarakat di perkotaan yang dikoordinir oleh orang dewasa untuk memperkerjakan mereka sebagai pengemis, pedagang cilik dll.

Sangat naif, ketika secara jujur tidak kita akui bahwa kuantitas pekarja anak (6-15 tahun) masih begitu signifikan dan sangat memprihatinkan di Negara kita dengan jumlah yang mencapai 1,7 juta anak. Walaupun dalam kurun waktu 20082014 ada 63.055 anak di seluruh provinsi di Indonesia yang ditarik dari pekerjaannya dan dikembalikan ke sekolah, namun setiap tahunnya pula akan muncul pekerja anak yang baru lagi. Sungguh sesuatu yang dilematis.(Harian Kompas, 31 Desember 2014). Data ini mengindikasikan bahwa persolan pekerja anak adalah masalah kompleks karena bukan hanya berbicara tentang upaya penarikan mereka dari lokasi pekerjaan ke habitusnya (keluarga : untuk mendapatkan kasih sayang dan bimbingan dari orang tua agar psikologi mereka bisa berkembang sesuai dengan tahapan perkembangan, juga lingkungan masyarakat dan pendidikan sekolah yang dapat membuat anak mengeksplorasi diri agar ditemukan bakat secara dini), namun lebih dari pada itu yakni upaya pencegahan yang terarah dan sistematis melalui kolektifitas lembaga yang berwenang, baik pemerintah maupun LSM yang ada termasuk juga lembaga hukum yang sebenarnya memiliki peran yang strategi demi memotong mata rantai krimanilatas yang dilakukan oleh orang-orang tertentu untuk mempekerjakan anak di bawah umur.

Kuantitas pekerjaan anak yang dipaparkan di atas memang sangat miris dan jauh dari harapan serta cita-cita bangsa bardasarkan UUD 1945 yakni, untuk mencerdaskan manusia Indonesia yang seutuhnhya.Upaya mencerdasakan manusia harus dilihat sebagai upaya penegasan keutuhan ciptaan Allah dan harus terstruktur pada elemen bangsa yang terkait.Baik pemerintah, orang tua dan juga lembaga keagamaan (gereja).Presensi dari elemen-elemen yang dimaksud, bagi penulis adalah ujung tombak dari peran yang harus diteruskan secara masif agar bisa mengembalikan nasib dari jutaan anak bangsa yang tak berdaya. 
"Grand topic" dari artikel ini yakni meninjau sisi etis kristani (deontologis) yang dijadikan sebagai alat uji untuk mereduksi dan menilai secara kritis peran central orang tua, gereja dan Pemerintah dalam memberdayakan kehidupan jutaan anak di dunia ini.

\section{B. Uraian Teoritis}

\section{> Anak Dalam Perspektif Psikologi Perkembangan}

Singgih D. Gunarsa dan Y Singgih D. Gunarsa, memberikan pendefenisian tentang anak adalah berdasarkan pada pengkategorian umur. Dimana yang disebut dengan anak adalah seseorang sejak lahir lalu melewati masa perkembangan fisik melewati masa balita yaitu (0-2 tahun), ketika berumur 3 tahun sampai 13 tahun, maka seseorang telah disebut sebagai anak. ${ }^{1}$ Dalam pengklasifikasian, yang disebut masa anak adalah masa balita, pra sekolah, masa anak sekolah dan masa remaja.

Dengan memakai pendekatan psikologi perkembangan manusia, Singgih D. Gunarsa menjelaskan, masa anak adalah masa di mana pertumbuhan fisik berjalan terus.Pertumbuhan yang dimaksud adalah suatu penambahan yang serasi, sehingga anak merupakan suatu kesatuan yang utuh. ${ }^{2}$ Itu berarti masa anak adalah bagian dari pembentukan diri sejak dini yang didapatkan dari pengaruh-pengaruh yang ada di luar maupun yang ada di dalam, yang ada diluar adalah pembentukan diri yang didapatkan dari keluarga dalam hal ini orang tua serta lingkungan sekitar sedangkan dari dalam yakni perkembangan secara medis yang lebih mengarah kepada pembentukan fisk berdasarkan tahapan-tahapan umur. Jika kedua hal ini dapat dijalankan secara utuh agar anak dapat terpenuhi kebutuhannya maka tak heran jika anak dalam masa pertumbuhannya bisa mencapai keserasian perkembangan.

Menurut Singgih, pada masa anak terlihat arah perkembangan dari suatu otonomi ke inisiatif, dengan demikian telah merangsang cara berpikir anak untuk menimbulkan keinginan-keinginan baru. Pada masa ini, anak-anak mempunyai kesempatan penting untuk mengembangkan perkembangan motorik dan ketrampilan lainnya yang diperoleh melalui proses kematangan dan latihan. ${ }^{3}$

Dalam pencapaian proses kematangan dan latihan-latihan, anak merupakan suatu individu yang bersifat terbuka terhadap orang tua sebagai peserta didik, ini adalah sikap kepolosan yang sudah ada dan melekat dalam diri anak, inilah 
keterbuakaan yang membuat sang anak masuk dalam ruang pengetahuan yang diberikan oleh orang tua, orang tua memiliki peranan yang sangat penting untuk meletakan dasar dan fondasi yang kuat melalui ajaran-ajaran yang diberikan. Untuk itu orang tua juga harus memiliki ruang pengetahuan yang luas agar mampu menjadikan anak sebagai peserta didik yang terampil, Sesuai dengan pemikiran ini, Belsky dan Bell seperti dikutip oleh Andiyani dan Kontjoro, menyatakan, anak-anak sangat memerlukan peranan orang tua (ayah dan ibu) dalam proses pendewasaan secara fisik dan psikologis, melalui pendewasaan tersebut, anak-anak akan belajar untuk mandiri, entah melalui proses belajar sosial dengan modeling atau pun melalui proses resiprokal dengan prinsip pertukaran sosial. Kalau yang pertama mengarah pada ketergantungan dari segi-segi penerapan pengetahuan dan pengalaman dari orang tua kepada anak, maka yang kedua, lebih mengarah kepada ketergantungan kebutuhan-kebutuhan yang dapat memenuhi segala kebutuhan pokok yang berkaitan dengan kelangsungan kehidupan dari seorang anak.

Kartini Kartono mengklasifikasikan anak pada usia sekolah dasar, yaitu : (1) pada umur 6-12. Pada usia sekolah ini, sikap hidup yang egosentris diganti dengan sikap yang "zakelijk" objektif dan empiris berdasarkan pengalaman; (2) pada usia 1314 tahun. Pada usia ini, sikap tersebut berkembang jadi logis rasionil. Pada fase ini, emosionalitas anak jadi makin berkurang, sedang unsur intelek dan akal budi (rasio, fakir) jadi semakin menonjol. ${ }^{4}$ Selanjutnya ia menjelaskan pula bahwa Pada umur pra remaja, anak tidak lagi banyak dikuasai oleh dorongan-dorongan endogen atau impuls-impuls intern dalam perbuatan dan fikirannya; akan tetapi lebih banyak dirangsang oleh stimulus-stimulus dari luar. Anak mulai belajar jadi seorang realiskecil, yang berhasrat sekali mempelajari dan 'menguasai" dunia secara obyektif.Dengan demikian, dalam aktifitasnya, anak memerlukan banyak informasi (pengajaran dan pendidikan). ${ }^{5}$ Berbicara mengenai perkembangan anak, berarti kita berbicara mengenai proses pertumbuhan dan pertumbuhan mempunyai kaitan dengan perkembangan individu seorang manusia. Dalam kaitannya dengan pokok pembahasan ini mengenai apa itu anak, maka sudah tentu, menunjuk pada suatu individu tertentu. Dengan demikian penulis, merasa perlu untuk memberikan suatu pengertian dasar mengenai individu dan kemudian, dilanjutkan dengan menjelaskan apa itu pertumbuhan, yang ada kaitannya dengan psikologi perkembangan anak yang 
terhubung dengan pendidikan sebagai sarana yang penting guna pembentukan karakter, kejiwaan dan identitas diri dari seseorang guna pengaktualisasian pribadi sesuai dengan kemampuan (ability) dan bakat-bakat (behavior).

Individu, berasal dari kata latin, "individuum" artinya "yang tak terbagi". Jadi, merupakan suatu sebutan yang dapat dipakai untuk menyatakan suatu kesatuan yang paling kecil dan terbatas. ${ }^{6}$ Dalam ilmu sosial paham individu menyangkut tabiatnya dengan kehidupan jiwanya yang majemuk, memegang peranan dalam pergaulan hidup manusia. ${ }^{7}$ Manusia, sebagai seorang individu, mempunyai daya gerak maju yang disebut dengan proses perkembangan individu. Proses yang meningkatkan ciri-ciri individualitas pada seseorang sampai pada dirinya sendiri, disebut proses individualisasi atau aktualisasi diri. ${ }^{8}$

Bergerak maju, sebagai suatu bentuk dari proses yang dinamis ke arah yang lebih baik adalah merupakan ciri khas dari perkembangan yang tidak terlepas dari subjektifitas pendidikan. Perkembangan, merupakan suatu kata sifat yang paralel dengan pertumbuhan.Ada berbagai macam defenisi mengenai pertumbuhan yang diberikan oleh berbagai aliran.Ahmadi, mendefenisikan pertumbuhan adalah suatu perubahan yang menuju ke arah yang lebih maju dan lebih dewasa. ${ }^{9}$ Pertumbuhan, menurut aliran asosiasi adalah pertumbuhan pada dasarnya adalah proses asosiasi. Pada proses asosiasi yang primer adalah bagian-bagian. Bagian-bagian yang ada lebih dahulu, sedang keseluruhan ada pada kemudian. Bagian-bagian ini terikat satu sama lain menjadi keseluruhan oleh asosiasi. ${ }^{10}$ Lain halnya dengan aliran psichologiGestalt yang memahami pertumbuhan sebagai proses diferensiasi. Dalam proses diferensiasi yang pokok adalah keseluruhan, sedang bagian-bagian hanya mempunyai arti sebagai bagian dari keseluruhan dalam hubungan fungsional dengan bagian-bagian yang lain. Jadi dapat disimpulkan, bahwa pertumbuhan itu adalah proses perubahan secara perlahan-lahan pada manusia dalam mengenal suatu yang semula mengenal sesuatu secara keseluruhan baru kemudian mengenal bagianbagian dari lingkungan yang ada. ${ }^{11}$ Selanjutnya, Wismoady Wahono mendefenisikan pertumbuhan adalah proses yang mencakup pertambahan dalam jumlah dan ukuran, keluasan dan kedalaman, dan sekaligus pertambahan dalam arti integrasi, saling keterhubungan dan kompleksitas. ${ }^{12}$ 


\section{$>$ Kesimpulan}

Berdasarkan uraian teoritis dari pendapat berbagai ahli psikologi perkembangan, yang telah diuraikan di atas, maka penulis dapat menyimpulkan bahwa anak dalam proses perkembangannya sangat membutuhkan bimbingan dari orang dewasa, bimbingan tersebut bertujuan agar si anak secara dini dapat membentuk pribadi mereka baik secara fisik, emosional dan kognitifnya menjadi satu individu yang utuh, untuk mengenal akan lingkungan social dimana mereka berada. Dan juga untuk mempersiapkan diri mereka sebagai individu-individu yang matang dalam rangka menghadapi perubahan-perubahan selanjutnya.

\section{Anak Dalam Perspektif Kerja}

Menurut kamus besar bahasa Indonesia (KBBI), kerja adalah perbuatan melakukan sesuatu atau sesuatu yang dilakukan. ${ }^{13}$ Dari pengertian ini maka dapatlah dikatakan, bahwa kerja adalah suatu tindakan yang dilakukan melalui gerakan fisik, dengan menggunakan akal untuk menciptakan suatu hal demi kebutuhan yang ingin dicapai.

Kerja membangun hubungan yang khas antara manusia dengan alam. Kerja memanusiawikan (menghumanisasikan) alam. Kerja membuat alam menjadi bagian dari dunia manusia. ${ }^{14}$ Thomas Aquinas, sebagaimana yang dikutip oleh Mudjisutrisno mengatakan bahwa kerja memungkinkan manusia mendapatkan pemilikan. Dengan kerja, manusia mewujudkan dirinya sebagai pribadi sehingga pada akhirnya, bagi Aquinas kerja inheren dalam sejarah manusia. ${ }^{15}$ Selanjutnya Mudjisutrisno juga mengutip pemahaman kerja dari hegel, yang mengatakan bahwa : Kerja manusia menunjukan adanya distansi antara subjek spritual dari objek material, yaitu manusia menggunakanobjek untuk memenuhi kebutuhannya dengan pertama-tama menangkapnya sebagai objek dan kemudian mengubahnya menjadi sesuatu yang lain. Dengan demikian kerja mendidik diri, mengungkapkan kebebasan dan otonomi manusia. $^{16}$

Hegel menempatkan pekerjaan dalam keseluruhan konteks kegiatan manusia. ${ }^{17}$ Ini berarti bahwa kerja merupakan bagian pokok yang ada dalam diri manusia. dengan kerja maka manusia dapat membanngun dan menghidupkan kehidupannya. 


\section{$>$ Kesimpulan}

Dari uraian teoritis dari para ahli di atas tentang pemahaman kerja, maka penulis menyimpulkan bahwa kerja merupakan upaya manusia untuk mengelolah, memperoleh dan memiliki sesuatu yang dikerjakan. Dengan kata lain, kerja mewakili tugas dan tanggung jawab manusia sebagai suatu bentuk tindakan sadar yang dilakukan, guna menghasilkan sesuatu dalam rangka untuk menjawab dan memenuhi akan kebutuhan hidup dari mansusia itu sendiri.

\section{Anak Dalam Perspektif Perlindungan Anak (Hukum)}

Pada bagian ini penulis akan menguraikan tentang apa itu pekerja anak dan perlindungan anak dan hak-hak anak sebagai bagian yang penting dalam rangka mengkaji megenai tindakan-tindakan yang dilakukan oleh berbagai pihak. Namun pada awal pokok bahasan ini, penulis akan lebih dahulu menguraikan tentang pengertian dari Hak Asasi Manusia (HAM).

Hak asasi manusia adalah hak yang dimiliki oleh manusia, bukan karena diberikannya oleh masyarakat atau hukum positif yang berlaku (negara), melainkan karena martabatnya sebagai manusia. ${ }^{18}$ Manusia adalah ciptaan Tuhan yang maha kuasa, yang memiliki hak asasi yaitu hal yang fundamental, universal dan melekat secara krodati pada diri setiap manusia, seperti hak hidup dan hak atas kehidupan. ${ }^{19}$ Manusia siapapun dia, tua atau muda, kaya atau miskin, cacat atau sehat, telah memiliki hak untuk hidup sejak dia dilahirkan.Untuk itulah maka hak asasi ini harus dijaga dan dijamin oleh pemerintah atan bahkan pihak-pihak lain yang berkepentingan.

Anak adalah bagian dari hak asasi tersebut, anak yang ada di seluruh dunia juga memiliki hak untuk di lindungi. Kedudukan anak sebagai generasi muda yang akan meneruskan cita-cita luhur bangsa, calon-calon pemimpin bangsa di masa mendatang dan sebagai sumber harapan bagi generasi yang terdahulu, perlu mendapat kesempatan seluas-seluasnya untuk tumbuh dan berkembang dengan wajar baik secara rohani jasmani dan sosial. Untuk itu, prlindungan anak harus merupakan usaha dan kegiatan seluruh lapisan masyarakat dalam berbagai kedudukan dan peranan yang menyadari betul pentingnya anak bagi nusa dan bangsa dikemudian hari. 
Kegiatan perlindungan anak membawa akibat hukum. Hukum merupakan jaminan bagi kegiatan perlindungan anak. Arif Gosita mengemukakan, bahwa kepastian hukum perlu diusahakan demi kelangsungan kegiatan perlindungan anak dan mencegah penyelewengan yang membawa akibat negatif yang tidak diinginkan dalam pelaksanaan perlindungan anak. ${ }^{20}$

Perlindungan anak dapat dibedakan dalam 2 bagian yaitu : perlindungan anak yang bersifat yuridis, yang meliputi : perlindungan dalam bidang hukum publik dan dalam bidang hukum keperdataan. Perlindungan anak yang bersifat non Yuridis, meliputi: perlindungan dalam bidang sosial, bidang kesehatan dan bidang pendidikan. ${ }^{21}$ Selanjutnya dalam Pasal 1 ayat 2 undang-undang no 23 tahun 2002 menentukan bahwa perlindungan anak adalah segala kegiatan untuk menjamin anak dan hak-haknya agar dapat hidup, tumbuh, berkembang dan berpartisipasi secara optimal sesuai dengan harkat dan martabat kemanusiaanm serta mendapat perlindungan dari kekerasan dan diskriminasi.

Perlindungan anak juga dapat diartikan sebagai segala upaya yang ditujukan untuk mencegah, merehabilitasi dan memberdayakan anak yang mengalami tindak perlakuan yang salah, eksploitasi dan penelantaran agar dapat menjamin kelangsungan hidup dan tumbuh kembang anak secara wajar, baik fisik, mental dan sosialnya. $^{22}$ Perlindungan anak bermanfaat bagi anak dan orang tuanya serta pemerintahnya, maka koordinasi kerjasama perlindungan anak perlu diadakan dalam rangka mencegah ketidak seimbangan kegiatan perlindungan anak secara keseluruhan. Untuk itu maka Arif Gosita mengatakan bahwa perlindungan anak adalah suatu usaha untuk melindungi anak agar dapat melaksanakan hak dan kewajibannya. $^{23}$

Perlindungan anak harus menyangkut segala aspek kehidupannya tanpa terkecuali, yang kesemuanya bertujuan agar anak dapat melangsungkan kehidupannya.

Pasal 6 Konvensi Hak Anak menyebutkan bahwa setiap orang agar dapat menjamin kelangsungan hidup juga perkembangan anak, memperhatikan kesehatan anak juga perawatan kesehatan. ${ }^{24}$

Menyangkut dengan kelangusngan hidup si anak, semua kalangan tentunya mempunyai peran yang sangat penting untuk melaksanakan jaminan tersebut, agar 
anak dapat hidup dan berkembang dengan semestinya.Di sini negara sangat memainkan peranan yang penting. Bisma Siregar mengatakan bahwa masalah perlindungan hukum bagi anak-anak indonesia. Masalahnya tidak diketahui secara yuridis, tetapi perlu pendekatan yang lebih luas, yaitu ekonomi, sosial dan budaya. ${ }^{25}$

Pasal 32 Konvensi Hak Anak menyebutkan bahwa negara juga berkewajiban untuk melindungi anak yang terlibat dalam pekerjaan, yang dapat membahayakan kesehatan dan perkembangan anak.Bagi penulis,peraturan ini mengandung maksud bahwa anak dalam menjalani kehidupannya tidak diperkenankan untuk bekerja. Menyangkut dengan peraturan ini maka penulis merasa pentingya untuk menguraikan tentang apa itu pekerja anak Pekerja anak adalah sebuah istilah untuk mempekerjakan anak kecil. Istilah pekerja anak dapat memiliki konotasi pengeksploitasian anak kecil atas tenaga mereka, dengan gaji yang kecil atau pertimbangan bagi perkembangan kepribadian mereka, keamanannya, kesehatan, dan prospek masa depan. ${ }^{26}$ Selanjutnya Tjandraningsih mengatakan bahwa Pekerja anak pada umumnya adalah : mereka yang bekerja di bidang-bidang marginal dan tidak memerlukan keterampilan khusus, seperti menjadi pembantu rumah tangga, buruh pabrik, buruh pada jermal-jermal, penjual koran, kuli angkut, penjual kaki lima, prostitusi dan pekerjaan seadanya (serabutan) lainnya. ${ }^{27}$ Melihat akan pemahaman serta keberadaan tentang pekerja anak di atas maka penulis dapat mengatakan bahwa yang ingin disoroti di sini adalah keberadaan dari sebuah lokasi dimana anak berkerja merupakan sebuah hal yang penting, kondisi kerja yang tidak memadai akan membawa anak kepada gangguan kesehatan serta keamanan yang tidak terjamin.

Selanjutnya mengapa pekerja anak itu harus ada? Bagi Moehamad Farid, hal utama penyebab anak bekerja adalah karena factor kemiskinan dan lemahnya legalisasi, menurutnya jika kelangsungan hidup keluarga menjadi terancam oleh kemiskinan, maka seluruh keluarga termasuk anak-anak terpaksa dikerahkan untuk mencukupi kebutuhan keluarga dan diri sisi legalisasi, tidak memadainya aturan yang melarang anak untuk bekerja. ${ }^{28}$ 


\section{$>$ Kesimpulan}

Hak asasi adalah hak dasar manusia yang dimiliki oleh manusia sejak kelahirannya tak terkecuali anak.Untuk itu anak adalah bagian dari perlindungan hukum.Upaya prlindungan hukum terhadap anak harus merupakan kegiatan dari segala pihak termasuk orang tua, agar anak dapat dilindungi dari berbagai kekerasan, salah satunya anak tidak diperbolehkan untuk melakukan pekerjaan (mengambil alih profesi sebagai pekerja anak), yang dapat mengganggu kesehatan fisik dan perkembangan psikologi .mereka.

Hukum merupakan jaminan dari kepastian atas kelangsungan hidup manusia dalam rangka menjalankan aktivitas kehidupan dari setiap manusia termasuk anakanak. Anak yang belum mampu melindungi diri mereka sendiri justru diberikan hakhak khusus seperti yang tertera di atas, hal ini sebagai upaya untuk mensejahterakan keberadaan anak di seluruh dunia. Secara luas, penjabaran hukum-hukum di atas tidak hanya terfokus pada sebuah segi kehidupan anak tapi justru di segala segi kehidipan anak.

Bagi penulis, melihat dan menanggapi akan bebagai hak yang tertuang dalam pengertian tentang perlindungan anak, perlu diberikan satu catatan kristis yakni, apakah peraturan-peratuaran tersebut talah menjangkau dan membebaskan kehidupan setiap anak dari keterpurukan? Jawabannaya adalah tidak. Berangkat dari realaita yang ada skarang ini, anak yang seharusnya berbusana hukum, masih dibiarkan terlantar begitu saja. Untuk itu lah maka peraturan-peraturan hukum di atas jangan hanya dijadikan sebagai sebuah konsep tanpa ada aksi yang kongkret untuk memerdekakan berbagai anak dalam keterpurukan

\section{E. Pembahasan}

\section{> Penilaian Etis Kristiani - Deontologis}

Berbicara tentang apa yang benar, apa yang salah dan apa yang tepat yang seharusnya dilakukan, adalah merupakan suatu cara berpikir yang terorientasi pada bagaimana melakukan pengambilan keputusan etis dengan mempergunakan pertimbangan-pertimbangan etika dengan prinsip-prinsip (deontologis, teleologis dan kontekstual). Dalam kajian ini penulis hanya memaparkan secara rinci penilaian etis 
kristiasni berdasar pada prinsip deontologis. Karena bagi penulis persoalan serius yang berhubungan dengan pekerja anak (tanpa mengabaikan persoalan lain yang menyebabakan anak mengambil profesi sebagai pekerja anak), adalah sejauh mana implemaentasi hukum atau aturan-aturan yang merupakan ruahdari pemebabasan anak dari segelintir manusia yang sengaja mempekerjakan anak usia sekolah ditindak dengan tegas. Marilah kita lihat, bagaimana prinsip etis ini menyoroti persoalan mengenai pekerja anak

Pengambilan keputusan etis deontologis atau dalam bahasa Joseph Flecher ${ }^{29}$ yaitu normative-absolut bertingkat adalah merupakan konsep berpikir yang mengacu pada hukum-hukum.Berbicara tentang hukum, berarti ada hukum-hukum sosial kemasyarakatan, hukum politik, hukum ekonomi dan lain-lain. Namun bila kita mau menarik konsep ini ke dalam pandangan Yudeo-Kristen, maka kita akan menemukan ada begitu banyak kesaksian Alkitab PL dan PB menguraikan tentang hukum-hukum yang terbagi atas hukum-hukum kemasyarakatan dan hukum-hukum keagamaan. Untuk itu, melalui pendekatan deontologis yang akan dijadikan sebagai landasan berpikir untuk suatu pengambilan keputusan etis, maka penulis akan menyertakan keputusan etis deontologis (normative-absolut bertingkat) ke dalam kehidupan pekerja anak.

Keadaan ekonomi orang tua yang miskin atau tidak mempunyai orang tua, mempunyai orang tua namun orang tua tidak memiliki pekerjaan/malas mencari pekerjaan, tidak ada perhatian dari masyarakat sekitar juga gereja dan pemerintah, aksi nakal para pengusaha industri yang sengaja mempekerjakan anak dibawah umur dengan upah yang rendah dll, sehingga mau tak mau anak harus bekerja untuk sesuap nasi, bekerja sebelum dan sesudah sekolah atau karena sudah putus sekolah, merupakan suatu gambaran kehidupan praktis yang sangat memprihatinkan. Praksis dari apa yang dilakukan oleh pekerja anak adalah sebuah pengkhianatan terhadap martabat kemanusiaan manusia untuk mendapat perlindungan secara moral yang telah diamandemenkan melalui Undang-Undang Hak-Hak Asasi Manusia (declaration of human right)). Secara tegas, hampir semua sistem perundangan dari berbagai perspektif(UU HAM, UU Sistem Pendidikan Nasional, UU Ketenagakerjaan, Konvesi Hak-Hak Anak) tidak menyetujui dan secara radikal melarang anak-anak untuk bekerja pada usia 6-15 tahun. Di usia ini, anak-anak 
belum pantas dan belum layak untuk bekerja, dimana mereka harus mendapat perhatian dan kasih sayang dari orang tua (orang tua Asuh), mereka harus belajar di Sekolah, mereka harus mendapatkan kesempatan untuk menikmati kesenangan melalui permainan yang juga menjadi motorik bagi perkembangan secara afektif dan kogniktif.Etika deontologis tidak lah melihat tentang tujuan dan akibat tetapi melihat tentang apa yang seharusnya dilakukan oleh orang tua, orang tua asuh, pemerintah dan gereja sebagai suatu bentuk loyalitas kepada perundang-perundangan perlindungan anak.

Anak sebagai manusia yang bermartabat, mempunyai hak untuk mendapatkan kehidupan layak. Kehidupan layak adalah kehidupan menjanjikan kebahagiaan di masa mendatang. Mengabaikan hak-hak anak untuk mendapat pendidikan di sekolah, tidak mendapat penghidupan ekonomi "makanan, pakaian dan tempat tinggal” yang layak, merupakan suatu bentuk tindakan kekerasan terhadap anak. Kekerasan merupakan kejahatan besar yang dilakukan oleh pihak-pihak tertentu, dalam hal ini orang tua, gereja dan pemerintah (jemaat dan masyarakat).

Pekerja anak, harus mendapat perhatian serius dari Pemerintah dan Gereja. Undang-Undang harus diterapkan secara konsisten. Biaya pendidikan bersubsidi yang dikeluarkan oleh pemerintah adalah merupakan suatu bentuk kebijakan yang dapat membantu anak-anak yang hidup dalam kemiskinan. Tapi, persoalannya tidak sampai pada hanya memberikan biaya pendidikan gratis, namun harus ada tindakan nyata dengan melakukan semua kebijakan-kebijakan hukum yang terstruktur atas dasar UU Hak-Hak Anak secara komprenhensif. Akar persoalannya tidak terletak pada biaya gratis, tetapi apa pentingnya biaya gratis, jika anak-anak tidak mempunyai biaya untuk mencukupi kehidupan makan, pakaian dan lain-lain dan ketika hal yang pokok belum terpenuhi maka inilah letak persoalannya yang membuat anak-anak terhisap sebagai pekerja. Pada akhirnya, apa pun alasan dan tindakan yang menyebabkan pekerja anak terus ada dan menghiasi lingkup social kemasyarakatan yang terus terjadi berlarut-larut tanpa ada penanganan yang menyeluruh dari pihak-pihak yang bertanggung jawab adalah merupakan suatu bentuk penyelewengan dan penghiatan besar terhadap segala konstitusi Hukum "UU tentang Hak-Hak Anak" dan tentu juga, secara iman "Yudio-Kristen adalah 
merupakan suatu tindakan keberdosaan karena mengabaikan perintah-perintah Allah terutama hukum kasih.

Terfokus pada kajian etis ini maka ganbaran manusia sebagai partner Allah tercermin dalam tugas dan tanggung jawab manusia untuk memanusiakan manusia yang lain. Anak yang adalah ciptaan Allah yang masih kecil dan masih lemah, harus dilihat sebagai sekumpulan manusia yang harus dilindungi dan dibimbing sehingga mereka bisa tumbuh manjadi manusia yang seutuhnya.

Ketika manusia yang mengambil Perjanjian sebagai partner Allah, maka anak harus mendapat kesempatan untuk belajar secara non-formal dan formal guna menemukan identitas dirinya sebagai manusia yang memiliki kemanusiaan untuk menunjukkan eksistensinya, sebagai ciptaan yang dapat menjalankan fungsi-fungsi dari panggilan dan perannya sebagai Partner (rekan kerja) Allah. Dengan pandangan ini, maka nyatalah, bahwa anak sebagai gambaran dari manusia yang sementara dalam masa-masa perkembangan secara kognitif maupun kognitif dan psikomotorik, diberikan suatu perhatian yang khusus dan istimewa sebagai generasi yang akan menciptakan sejarah peradaban baru tanpa meninggalkan makna intersubjektifitas "partner Allah" (co-creator). Guna terwujudnya, panggilan dan tanggung jawab sebagaimana gambaran intersubjektifitas, Kitab Ulangan 6 : 6-8 dengan jelas mengatakan:

Apa yang kuperintahkan kepadamu pada hari ini haruslah engkau perhatikan, haruslah engkau mengajarkannya berulang-ulang kepada anak-anakmu dan membicarakannya apabila engkau duduk di rumahmu.

Apabila engkau sedang dalam perjalanan, apabila engkau berbaring, dan apabila engkau bangun.

Haruslah juga engkau mengikatkannya sebagai tanda pada tanganmu dan haruslah itu menjadi lambang di dahimu.

Dan haruslah engkau menuliskannya pada tiang pintu rumahmu dan pada pintu gerbangmu.

Ayat ini, mempunyai makna imperatif sebagai suatu landasan yang menyatakan, bahwa pentingnya peran orang tua dan manusia dewasa lainnya termasuk pula lembaga grejawi dan pemerintahuntuk mendidik anak, agar jangan anak-anak terjebak pada tindakan-tindakan yang bertolak-belakang dengan makna dan arti dari hubungan intersubjektifitas. Perkembangan moral anak, dapat 
ditentukan melalui perkembangan iman kepercayaan anak kepada Allah Sang Creator. ${ }^{30}$ Bagi penulis, kitab Ulangan 6:6-10, merupakan suatu bentuk tugas panggilan kepada pihak-pihak yang terkait, yakni memberitakan kepada anak-anak tentang keagungan perbuatan-perbuatan Tuhan, berdasarkan cerita pada bagian kitab ini, kita bisa lihat bahwa bangsa Israel pada saat itu sedang berada dalam situasi perbudakan yang dilakukan oleh bangsa Mesir, situasi perbudakan yang dihadapi akan membawa tekanan psikologi bagi umat Israel tak terkecuali anak-anak sehingga dapat mnyebabkan gangguan perkembangan psikologi mereka. Untuk itu maka Allah menginginkan agar mereka juga harus dibebaskan dari tekanan tersebut dan inilah sejatinya kepedulian Allah kepada anak-anak .

Alkitab menyaksikan, anak-anak sebagai individu yang sementara berkembang menuju pada penemuan bakat-bakat dan kemampuan intelektual dalam rangka untuk mengaktualisasikan dirinya, sebagai suatu pribadi yang mempunyai integritas yang dapat memberikan gambaran sebagai makhluk yang berahklak dan bermoral bedasarkan iman percayanya dan mempunyai rangsangan dari dalam untuk mengetahui tentang sesuatu yang diperhadapkan padanya (kejadian, peristiwa, dll”) Maka, semua elemen terkait bertanggungjawab untuk memberikan jawaban-jawaban yang rasional dan yang masuk akal guna mengintegrasikan nilai-nilai "iman" kepada si anak, (Kel $12: 26 ; 13: 14^{31}$ ), telah menjadi rujukan yang harus menjadi tugastugas elementer dari para orang tua dalam mendampingi anak-anak dalam pertumbuhan menuju pada kedewasaan iman. Tentu saja bukan hanya mengenai pengetahuan iman yang menjadi harapan dari anak-anak, namun jauh dari itu adalah meresponi jawaban iman, harus juga diikutsertakan dengan pengenalan akan pengetahuan dalam segala hal yang dapat membuat anak-anak mampu menjadi manusia-manusia yang sempurna sesuai dengan harapan Allah.

\section{$>\quad$ Kesimpulan}

Dari pokok-pokok pikiran yang telah tertuang secara terbuka dalam tulisan ini, maka sangat diharapkan adanya kebijakan-kebijakan yang terintegrasi dalam berbagai peraturan, yang punya kaitan dengan kesejahteraan anak sebagai tindak lanjut dari pada hukum yang belum teralisasi secara maksimal. Secara etis kristiani, ketika kita membiarkan anak-anak terus bekerja sebagai pekerja usia muda, maka itu 
merupakan suatu bentuk pengkhianatan akan ajaran kasih Kristus yang di dalamnya terkandung nilai pembebesan dalam perspektif keadilan dan kesejahteraan.

\section{Endnote :}

${ }^{1}$ Singgih D. Gunarsa dan Y. Singgih D. Gunarsa, Psikologi Praktis, Anak, Remaja dan Keluarga,
(Jakarta : BPK Gunung Mulia, 1991 ), h. 6.
${ }_{2}^{2}$ Singgih D. Gunarsa dan Y. Singgih D. Gunarsa, Psikologi Praktis, Anak, Remaja,... h.8
${ }^{3}$ Singgih D. Gunarsa dan Y. Singgih D. Gunarsa, Psikologi Praktis, Anak, Remaja ..., h.9
${ }^{4}$ Kartini Kartono, Psikologi Anak Psikologi Perkembangan, (Bandung : Mandar Maju, 1990), h. 136-
${ }_{137 .}$ 137.

${ }^{5}$ Kartini Kartono, Psikologi Anak Psikologi..., 137.

${ }^{6}$ H. Abu Ahmadi, Ilmu Sosial Dasar, (Jakarta : PT Rineka Cipta), h. 74.

${ }^{7}$ H. Abu Ahmadi, Ilmu Sosial Dasar, (Jakarta : PT Rineka Cipta), hlm. 74.

${ }^{8}$ H. Abu Ahmadi, Ilmu Sosial Dasar, (Jakarta : PT Rineka Cipta), hlm. 75.

${ }^{9}$ H. Abu Ahmadi, Ilmu Sosial Dasar, (Jakarta : PT Rineka Cipta), hlm. 76.

${ }^{10}$ H. Abu Ahmadi, Ilmu Sosial Dasar, (Jakarta : PT Rineka Cipta), hlm. 76.

${ }^{11}$ H. Abu Ahmadi, Ilmu Sosial Dasar, (Jakarta : PT Rineka Cipta), hlm. 77.

${ }^{12}$ S. Wismoady Wahono, Ph.D, Di Sini Kutemukan, (Jakarta : BPK Gunung Mulia, 1998), h. 485

${ }^{13}$ Kamus Besar Bahasa Indonesia(KBBI), (Jakarta : Debdikbud 1991) h. 92

${ }^{14}$ M. Sastrapratedja, Kebudayaan Ditinjau Dari Segi Filsafat.Dalam,F.X. Mudjisutrisno, Manusia Dalam Pijar-pijar Kekayaan Dimensinya. (Yogyakarta : Kanisus 1993) h 91

${ }^{15}$ M. Sastrapratedja, Kebudayaan Ditinjau Dari Segi Filsafat...,h.91

${ }^{16}$ M. Sastrapratedja, Kebudayaan Ditinjau Dari Segi Filsafat...,h.91

${ }^{17}$ Soerjono Poerpwardoyo dan K. Bartens, Sekitar Manusia(Jakarta : PT Gramedia 1983) h 74

${ }^{18}$ Kanter E.Y, Etika profesi hukum, (Jakarta : Storia Grafika 2002), h 23

${ }^{19}$ Muhamad Joni dan Zulchaina Tanamas, Aspek Hukum Perlindungan Anak Dalam perspektif Konvensi Hak-Hak Anak, (Bandung : PT Citra Aditya Bakti 1999), h 1

${ }^{20}$ Arif Gosita,Masalah Perlindungan Anak, (Jakarta : Akedemika Presindo, 1997). h 19

${ }^{21}$ Arif Gosita,Masalah Perlindungan Anak..., h.19

${ }^{22}$ Konvensi Media Advokasi dan Pengakan Hak-hak Anak, (Medan : Lembaga Advokasi Anak Indonesia 1998) h. 3

${ }^{23}$ Konvensi Media Advokasi dan Pengakan Hak-hak Anak, h. 3

${ }^{24}$ Muhamad Joni dan Zulchaina Tanamas, Aspek Hukum Perlindungan h 35

${ }^{25}$ Bisma Siregar, dkk. Hukum dan hal-hak anak (Jakarta : Rajawali, 1986) h 2

${ }^{26}$ (http://id.wikipedia.org/wiki/Pekerja_anak)

${ }^{27}$ Tjandraningsi, Membangun Jaringan Kerjasama Hak Asasi Manusia, (Jakarta : Komisi Nasional Hak Asasi Manusia 1998) h 7

${ }^{28}$ Moehamad Farid,Jurnal Analisis Sosial (Bandung : Yayasan Akatiga 1997), h 10

${ }^{29}$ Normativ - Absolut bertikat, merupakan kata yang dipakai oleh Joseph Flecher untuk membuat suatu kajian terhadap suatu pimikiran, keputusan dan tindakan. Kata ini dipakai juga oleh Norman L. Geisler, Ph.D, di dalam bukunya yang berjudul : Etika Kristen Pilihan dan Isu

${ }^{30}$ Jhon M. Drescher, Tujuh Kebutuhan Anak (Jakarta : BPK Gunung Mulia 1997) h. 121

${ }^{31}$ Kel $12: 26$ : Dan apabila anak-anakmu berkata kepadamu (kalimat tanya) : Apakah artinya ibadahmu ini ? maka haruslah kamu berkata : Itulah korban... 


\section{DAFTAR PUSTAKA}

Ahmadi Abu H., 2000. Ilmu Sosial Dasar. Jakarta : PT Rineka Cipta.

Drescher M. Jhon, 1997.Tujuh Kebutuhan Anak. Jakarta : BPK Gunung Mulia.

Farid Moehamad,1997. Jurnal Analisis Sosial. Bandung : Yayasan Akatiga.

Gosita Arif,1997. Masalah Perlindungan Anak. Jakarta : Akedemika Presindo.

Geisler L. Norman, di dalam bukunya yang berjudul : Etika Kristen Pilihan dan Isu

Gunarsa D. Singgih dan Gunarsa D. Singgih/Y, 1991. Psikologi Praktis, Anak, Remaja dan Keluarga. Jakarta BPK Gunung Mulia.

Joni Moehamad dan Tanamas Zulkainah, 1999. Aspek Hukum Perlindungan Anak Dalam perspektif Konvensi Hak-Hak Anak, Bandung : PT Citra Aditya Bakti.

Kartono Kartini, 1990. Psikologi Anak (Psikologi Perkembangan. Bandung : Mandar Maju.

Konvensi Media Advokasi dan Pengakan Hak-hak Anak, 1998.Medan : Lembaga Advokasi Anak Indonesia.

Poerpwardoyo Soerjono dan Bartens K., 1983. Sekitar Manusia. Jakarta : PT Gramedia.

Sastrapratedja M, "Kebudayaan Ditinjau Dari Segi Filsafat”.Dalam, F.X. Mudjisutrisno, 1993.Manusia Dalam Pijar-pijar Kekayaan Dimensinya, Yogyakarta : Kanisus.

Siregar Bisma dkk. 1986. Hukum dan Hal-Hak Anak, Jakarta : Rajawali.

Tjandraningsi, 1998. Membangun Jaringan Kerjasama Hak Asasi Manusia,Jakarta : Komisi Nasional Hak Asasi Manusia .

Wahono Wismoyadi, 1998. Di Sini Kutemukan, Jakarta : BPK Gunung Mulia.

Y.E. Kanter, 2002. Etika Profesi Hukum. Jakarta : Storia Grafika.

\section{Sumber lain:}

LAI, Alkitab, Jakarta 1992

Harian Kompas, 31 Desember 2014 